Tourism Research Journal

E-ISSN: 2598-9839

2020, Vol. 4 No. 2

\title{
The Development of Thematic Tourist Village of Mulyaharja Bogor Based on Community Empowerment Approach
}

\author{
Asep Parantika ${ }^{1}$, FX Setiyo Wibowo ${ }^{2}$, Kadek Wiweka ${ }^{3}$ \\ 1,2Sabid Polytechnic \\ ${ }^{3}$ Universite Angers \\ *fxsetiyowibowo@polteksabid.ac.id
}

\begin{abstract}
The study aims to find out the solving method for problems in the thematic tourist village of Mulyaharja and designing the development of thematic tourism village model based on a community empowerment approach. This study is qualitative with an action research method. There are five respondents, i.e. chief of the village office, secretary of the village office, manager of the thematic tourist village, leader of mature farmer group and chief of youth group organization. This study was undertaken from February, 2018 to September, 2019. The generated outcomes are a solving problem method as solving steps chart, which consists of an explanation of the problem, solving and progress report each aspect, institutional, vision, activity, amenities, accesbility and entrepreneurship aspect. Furthermore, the model designed for development of thematic tourist village based on community empowerment is a circle with series of steps of eleven steps that connected each other and continuity. The series of steps are 1) choosing the candidate of partner village; 2) deciding the category of tourist village; 3) executing the MoU; 4) determining the program targets; 5) identifying the potentials of tourist village; 6) managing the empowerment programs; 7) implementing the assistance programs; 8) directing the college resources; 9) promoting the outcome of program; 10) evaluating the program and 11) mapping the stakeholder based on their proactive involvements.
\end{abstract}

Keywords: Development, Thematic Tourist Village, Community Empowerment Approach

Tourism Research Journal, Volume 4 (2), 2020 
The Development of Thematic Tourist Village of Mulyaharja Bogor Based on Community Empowerment Approach

\section{A. Introduction}

A thematic tourist village in Ciharashas, Bogor regency, West Java province, Indonesia is Mulyaharja with organic rice as its main product. Organicbased farming system produces organic rice which is developed with organic fertilizer. Organic rice contains high nutritional and vitamin needed by the human body. It is processed and developed with organic fertilizer, it does not contain chemical fertilizer, so it is very safe to consume by human body. The organic fertilizer used comes from rice straw and cow manure. Build upon the explanation of Bang Oji, chief of Karangtaruna, a local based Indonesian youth organization, there are a lot of organic rice requests from consumers in the greater Jakarta area, a capital city of Indonesia. It means that organic rice production in Mulyaharja thematic tourist village has not been able to meet market demand. Those are because the capacity area of organic rice fields in Mulyaharja is still plenty, just a small part of farmers who apply the organic agriculture system. Many others still use a conventional manner. This is because of farmer realm still argue that organic farming requires a longer time to harvest their paddy and it's period of tillage and fertilization requires more time, cost and energy. Even it is recognized that the price of organic rice is far more expensive than the ordinary one.

Basically, the costs of planting and processing as well as the income generated after harvest between organic and ordinary rice is generally similar, but it is not easy to change most of farmer opinion switching from the conventional to organic manner. Because of the hard work and efforts carried out, Mulyaharja thematic tourist village received awards and joined the national leading village competition. In 2018, infrastructure development was started to be obtained by Bogor regency government in order to support the organic agriculture system. Kampung (village) Ciharashas, RT 05/01 Mulyaharja sub-district, South Bogor, Bogor City has tremendous potential in its organic agriculture. The village, known as Lemah Duhur, was changed into a thematic tourist village and carried organic agro tourism. "The team from the department of agriculture as extension agents, village office, the school of agricultural counseling (Sekolah Tinggi Penyuluhan Pertanian), youth organization (KarangTaruna) and the adult farmer group (Kelompok Tani Dewasa) Lemah Duhur are dealing to carry it out," said the head of Bogor agricultural extension at Bogor city agriculture office (Dinas Pertanian Kota Bogor), Dian Herdiawan.

The village of Ciharashas had previously participated in a thematic tourist village innovation competition organized by the Bogor city planning and development agency (Bappeda) in 2017. A team of various stakeholders was created for the success of the village. Bapak Aneng as the leader of Lemah Duhur adult farmer group, contribute his land to facilitate the beginning of its activities. This collaboration resulted in an award, namely recognition from the organic certification institute and winning the thematic village innovation competition. "After winning competition in December 2017, the organic

Tourism Research Journal, Volume 4 (2), 2020 
The Development of Thematic Tourist Village of Mulyaharja Bogor Based on Community Empowerment Approach

edutourism agro village began to be opened to the public. This is as a forum to provide basic education in theory and practice of organic farming," Dian continued. Many knowledges and theories can be learned in this village. They learn rice cultivation, cattle, and introducing biogas from livestock manure. In addition to providing educational agro-tourism, this village also provides a variety of arts and cultural performances. Starting from gendang pencak (the traditional drum performance), playing traditional games, also susur sungai (the river adventure). Although relatively recently opened, many schools from Bogor city and outside have come to study in the village. Many participants follow the farm learning package and spend the night at the farmer's house (republika.co.id, 2018). Depart from the dominant agricultural sector and the tourism sector which began to develop, it is suitable if the two sectors are combined into one interesting and educational tourist attraction, namely agro-tourism.

Apart from the above potential, several problems were found, namely rubbish which shows the lack of public awareness to maintain village cleanliness. Furthermore, accommodation facilities that have not been developed yet; this is evidenced by improper home maintenance, does not meet the requirements as a homestay. The village's condition, which was still makeshift, indicated the lack of awareness about eight tourism tagline (Sapta Pesona), presumably the community was still concerned on agriculture alone, had not developed yet into a tourist destination even though there is a paradigm about creating tourist village among of them. Next, there is lack of 4A (accessibility, attraction, amenities and ancillary) or tourist studies about something to see, something to do, something to buy. Then, there were still two new businesses that have been set up, namely cassava chips business and Dodol, so there are still very small numbers of entrepreneurs who can cultivate their local potential.

One of the social degradations is the moving of the young generation to the big city to get a job that causes the village to be abandoned by youths who are actually village strategic assets that must be maintained considering they have a lot of energy, full of creative and innovative ideas. (Wibowo and Damanik, 2019). Paying attention to this condition, Sahid Polytechnic as tourism academicians, wishes that Mulyaharja thematic tourist village can become a successful tourist destination with agriculture education-based and become a valuable asset in Bogor regency and Indonesia by implemented programs. According to those kinds of issues, this study aims to find out the solving method to overcome the problems and to design a model to develop Mulyaharja thematic tourist village with a community empowerment approach. 
The Development of Thematic Tourist Village of Mulyaharja Bogor Based on Community Empowerment Approach

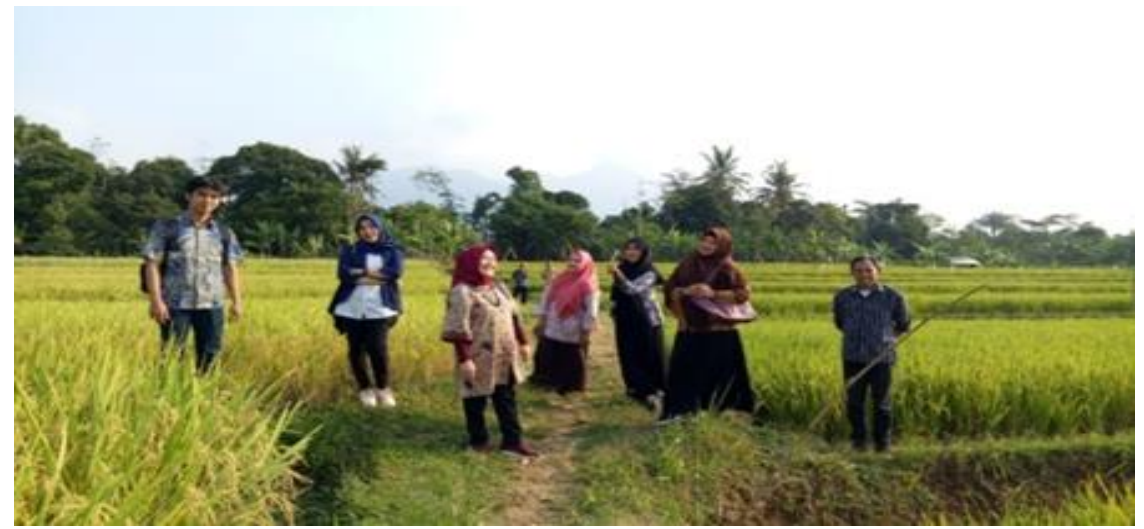

Figure 1. The Beauty of MulyaharjaOrganic Rice Fields Thematic Village

\section{B. Literature Review}

\section{Organic Agriculture}

Organic farming is a holistic farming system that supports and accelerates biodiversity, biological cycles and soil biological activities. Certification of organic products produced, storage, processing, post-harvest and marketing must comply with standards set by the standardization body. "Organic" is a labeling term that states a product has been produced in accordance with organic production standards and is certified by an official authority or certification body. Organic farming is based on the use of minimum external input, and avoids the use of synthetic fertilizers and pesticides. Organic farming practice cannot guarantee that its products are completely free of residues due to general environmental pollution. However, several methods are used to reduce pollution from air, soil, and water. Workers, processors, and organic food traders must comply with standards to maintain organic agricultural products' integrity. Organic farming's main objective is to optimize the health and productivity of the interdependent community of life on land, plants, animals, and humans (Mayrowani, 2012).

\section{Agrotourism}

Agro-tourism is defined as an agribusiness activity when a local farmer offers a tour of his farming business and allows a visitor to witness the growth, harvesting, processing of local food that will not be found in his home area, so that agro-tourism can be new hope and also an opportunity to the farmers to be more creative in managing their farming business. It is expected to be able to deliver products that able to touch the hearts of tourists to come and to visit repeatedly. Agricultural products that are appropriate and can be absorbed or utilized by relevant stakeholders, will greatly help to increase the income of farmers and related stakeholders (Gurindawangsa et al., 2017). 
The Development of Thematic Tourist Village of Mulyaharja Bogor Based on Community Empowerment Approach

\section{The Thematic Village}

The thematic village began to be implemented in mid-2016 to overcome poverty, especially the problem of meeting basic needs, encouraging the local economy by exploring society's economic potential as a stimulus for regional development and improving the quality of the community's home environment. A thematic village is also linked to development oriented to the formation of ideas, creative and unique topics. The concept of thematic villages offers more people to be more proactively involved, then it is not only community-based but also the creation of distinctively characteristic village spaces by the community. Born from the creative ideas of the community and the society, thematic villages can also be called a social innovation. The implementation of the thematic village concept based on the social innovation scheme has three stages. The first stage is problematic mapping, where people look for ideas or methods in developing their villages to create jobs and increase local community participation. The second stage is determining the village's theme by finding a group of people interested in working together in applying ideas or themes to the village. The third stage is delineation and coordination through ideas or themes that are then modified by sharing the actors involved until finally they are implemented in the region (Tamara and Rahdriawan, 2016).

\section{Tourist Village}

The tourist village is a rural area that has several special characteristics to become a tourist destination. Pariwisata Inti Rakyat (PIR) defines a tourist village as a rural area that offers an overall atmosphere that reflects the rural authenticity of both socio economic, socio-cultural, traditional, daily life, has a building architecture and village spatial structure that unique, or creative and interesting economic activities that have the potential to develop various components of tourism, such as attractions, accommodation, food and beverages and other tourism needs (Hadiwijoyo, 2012). Based on the level of development, tourist villages are divided into three categories as follows (Simanungkalit et al., 2012):

1. Embryo tourist village is a village that has tourism potential that can be developed into a tourist village and there has been a community movement to manage it into a tourist village.

2. Developing tourist villages is embryo tourist villages managed by the community and village government independently. They have started to carry out promotions and there are already tourists who are interested in visiting.

3. The developed tourist village is a tourist village that has developed with continuous tourist visits and managed professionally to form a management forum, such as cooperatives or village-owned enterprises (BUMDes). This category of tourist village has been able to do promotion and marketing well.

Meanwhile, based on the characteristics of the resource and its uniqueness, the tourist villages are grouped in four categories as follows (Wahyuni, 2018):

Tourism Research Journal, Volume 4 (2), 2020 
The Development of Thematic Tourist Village of Mulyaharja Bogor Based on Community Empowerment Approach

1. Tourist village based on the uniqueness of local cultural resources as the main tourist attraction.

2. Tourist villages based on natural resources' uniqueness as the main attractions such as mountains, villages and agriculture, coastal areas.

3. Tourist village based on a unique blend of cultural and natural resources as the main attraction.

4. Tourist villages based on unique creative economic activities such as the handicraft industry are the main tourist attractions.

The objectives of developing tourist villages includes (Wardhani, 2016):

1. Supporting government programs in tourism development by providing alternative tourist objects.

2. Explores the potential of the village for community development around the tourist village.

3. Expand employment and business opportunities for villagers, so that they can improve the welfare and quality of life of rural communities.

4. Generating a sense of pride for villagers to remain in their villages.

5. Accelerating the intermingling between non-native people and the indigenous population, for example, tourists and local people.

\section{Community Empowerment}

The process of community empowerment through the development of a tourist village is carried out in three stages, those are the stage of socialization, the stage of transformation of ability, and the stage of independence (Hendryantoro, 2014). In general, empowerment implies a process towards empowerment. The notion of "process" refers to a series of steps carried out in stages to transform a community that is lacking or helpless into empowered. In line with this understanding, empowerment has two meanings: giving power or authority and giving the ability to or enable (Wahyuni, 2018).

\section{Assistance}

The purpose of assistance is to teach certain groups to meet their needs and abilities based on interaction from, by, and for members in the group and solidarity between groups to improve their welfare with the help and role of a companion. Assistance is a process of accompanying and accompanying close, friendly and siblings, living together in joy and sorrow, and facing life in achieving the desired common goal (Kementerian Pariwisata, 2019).

\section{Research Methodology}

This research is a field research, the data collection is carried out in the field to make observations of a phenomenon in a natural state (Susanto, 1999). This research is qualitative in nature, namely research used to understand phenomena about what is experienced by research subjects, such as behavior, perception, motivation, actions, etc., holistically, and using descriptions in the

Tourism Research Journal, Volume 4 (2), 2020 
The Development of Thematic Tourist Village of Mulyaharja Bogor Based on Community Empowerment Approach

form of words and language, in a specific context natural and by utilizing various scientific methods (Moleong, 2008). The descriptive approach to gathering information about a symptom's status is not intended to measure certain hypotheses, but only describes what it is about variables, symptoms, and circumstances (Arikunto, 1998).

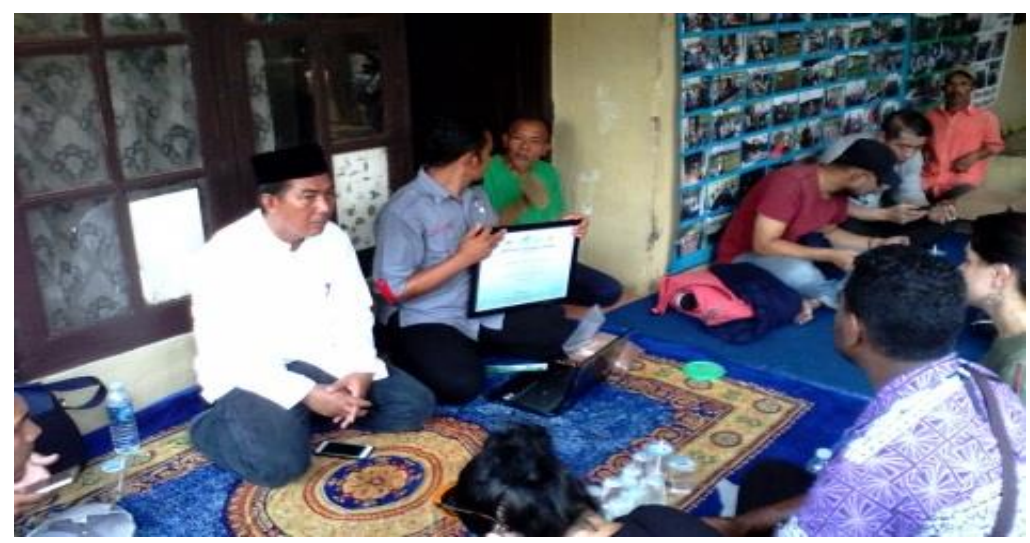

Figure 2. Focus Group Discussion

\section{The Unit Analysis.}

The unit analysis used in this study is Mulyaharja thematic tourist village, South Bogor, West Java, Indonesia.

\section{Key Informan}

In this study used five speakers who are actors in the Mulyaharja thematic tourist village, namely Bang Oji as chairman of youth organization, Mas Imam as thematic tourist village manager, Bapak Aneng as chairman of Lemah Duhur adult farmer group, Pa Gandi as secretary of village office and Bapak Sofyan Makmur as head of village office.

\section{Data Collection}

Primary data was collected from the results of interviews with resource persons, then concluded related to empowerment programs that have been and will be carried out to get to the tourist village. Meanwhile, secondary data was obtained from reference books, online media and (kemendagri, 2019) regarding general data and geography. The data collection method used is triangulation. Triangulation is "the aim is not to determine the truth about the same social phenomenon, rather than the purpose of triangulation is to increase one's understanding of whatever is being investigated." Thus, triangulation is not intended to seek the truth, but to increase researchers' understanding of the data and facts they have. Triangulation is a qualitative cross-validation. It assesses the data's sufficiency according to the convergence of multiple data collection or multiple data collection procedures (Sugiyono, 1997).

Tourism Research Journal, Volume 4 (2), 2020 
The Development of Thematic Tourist Village of Mulyaharja Bogor Based on Community Empowerment Approach

Triangulation in credibility testing is defined as checking data from various sources in various ways. At various times, triangulation can be grouped into three types, namely source triangulation, triangulation of data collection techniques, and time. In this triangulation study with three data sources, namely village officials (Lurah and Seklur), thematic tourist village managers and other groups (adult farmer groups and youth clubs). While triangulation with three data collection techniques, namely interviews, observation and Focus Group Discussion (Bachri, 2010).

\section{Research implementation}

The place and time of the research were held in Mulyaharja thematic tourist village, Bogor, from February 2018 to September 2019. (Politeknik Sahid, https://www.youtube.com/watch?v=PY1ph7d-Yi0, 2019).

\section{Result and Discussion}

\section{Geographic data}

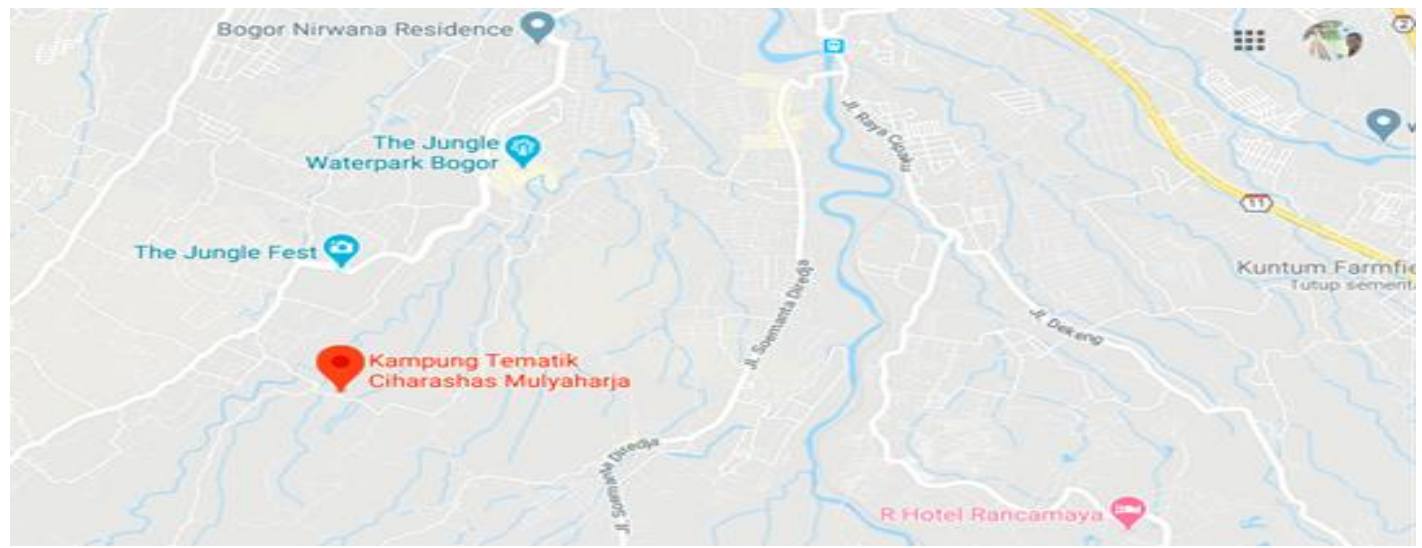

Figure 3. Map of thematic villages Mulyaharja

Table 1. Geography Data

\begin{tabular}{ll}
\hline Year & 2018 \\
\hline Village/Village Office & Mulyaharja \\
Sub District & West Bogor \\
District/City & Bogor City \\
Province & West Java \\
Year of formation & 2001 \\
Wide area/Village & 477,000500 \\
office (Ha) & \\
Coordinate & 106.789373 \\
& BT/-6.634659 \\
& LS \\
Typology & Rice fields
\end{tabular}

Tourism Research Journal, Volume 4 (2), 2020 
The Development of Thematic Tourist Village of Mulyaharja

Bogor Based on Community Empowerment Approach

\begin{tabular}{lc}
$\begin{array}{l}\text { Classification } \\
\text { Category } \\
\text { Borderline : }\end{array}$ & $\begin{array}{l}\text { Self-help } \\
\text { Madya }\end{array}$ \\
$\begin{array}{l}\text { a. Northern } \\
\text { Village/village } \\
\text { office }\end{array}$ & $\begin{array}{c}\text { Cikaret village } \\
\text { office }\end{array}$ \\
b. Southern & Sillage/village \\
office & village \\
c. Eastern & Pamoyanan \\
Village/village & village \\
office & office \\
d. Western & Sumantri \\
\multicolumn{2}{l}{ village } \\
\hline Source :(Kemendagri, 2019)
\end{tabular}

\section{General Data}

Table 2. Land Use

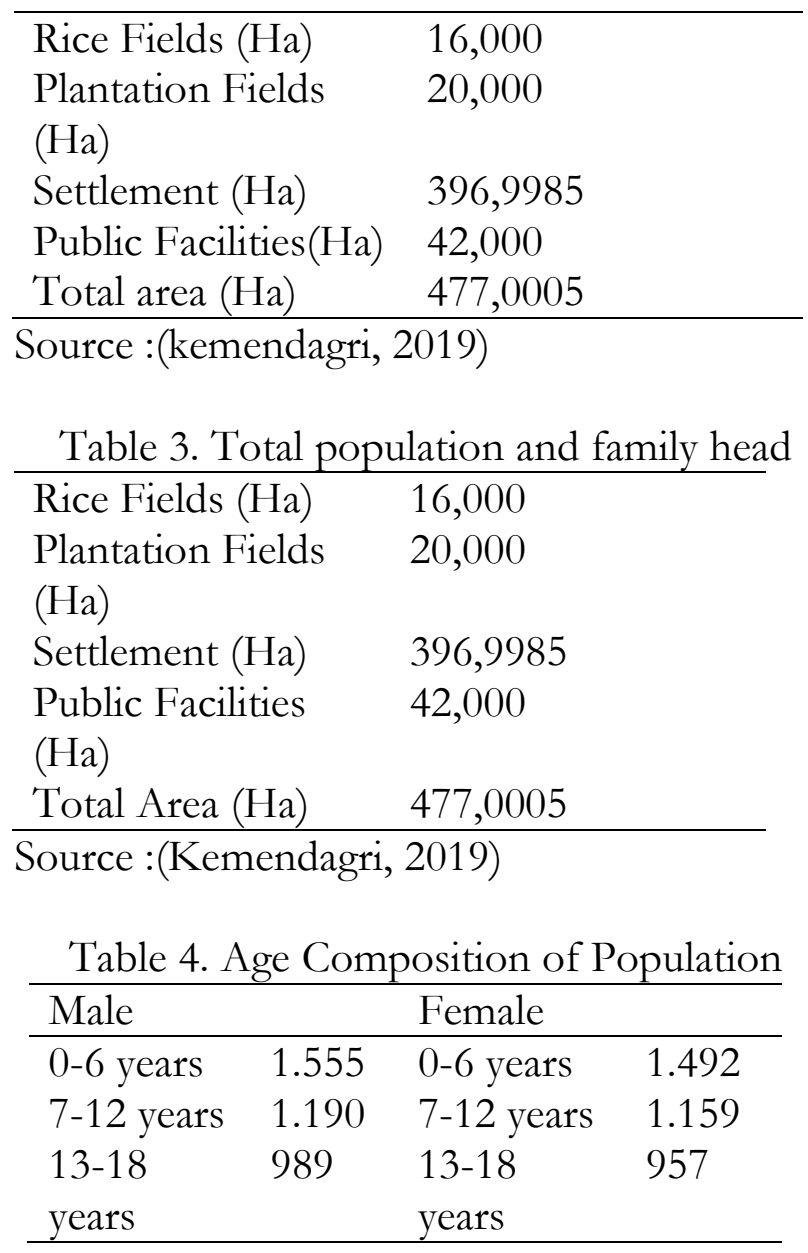

Tourism Research Journal, Volume 4 (2), 2020 
The Development of Thematic Tourist Village of Mulyaharja

Bogor Based on Community Empowerment Approach

\begin{tabular}{|c|c|c|c|}
\hline $19-25$ & 1.210 & $19-25$ & 1.169 \\
\hline years & & years & \\
\hline $26-40$ & 2.001 & $26-40$ & 1.893 \\
\hline years & & years & \\
\hline $41-55$ & 1.638 & $41-55$ & 1.553 \\
\hline years & & years & \\
\hline $56-65$ & 530 & $56-65$ & 447 \\
\hline years & & years & \\
\hline $65-75$ & 235 & $65-75$ & 139 \\
\hline years & & years & \\
\hline$>75$ years & 21 & $>75$ years & 12 \\
\hline Total & 9.348 & Total & 8.809 \\
\hline
\end{tabular}

Table 5. Family Welfare

\begin{tabular}{ll}
\hline $\begin{array}{l}\text { Pre-prosperity (Head of } \\
\text { family) }\end{array}$ & 1.410 \\
\hline Welfare 1 (Head of Family) & 1.421 \\
Welfare 2 (Head of Family) & 1.522 \\
Welfare 3 (Head of Family) & 381 \\
Welfare 3+ (Head of Family) & 215 \\
Total of Head of Family & 4.949 \\
\hline
\end{tabular}

Source :(Kemendagri, 2019)

Table 6. Types of Employment

\begin{tabular}{llll}
\hline Education Level & Male & Female & $\begin{array}{l}\text { Total } \\
\text { (people) }\end{array}$ \\
\hline Elementary & 194 & 191 & 385 \\
Junior High School & 163 & 158 & 321 \\
Senior High School & 134 & 129 & 263 \\
Total & 491 & 478 & 969 \\
\hline
\end{tabular}

Source :(Kemendagri, 2019)

\section{Solving Problem Method}

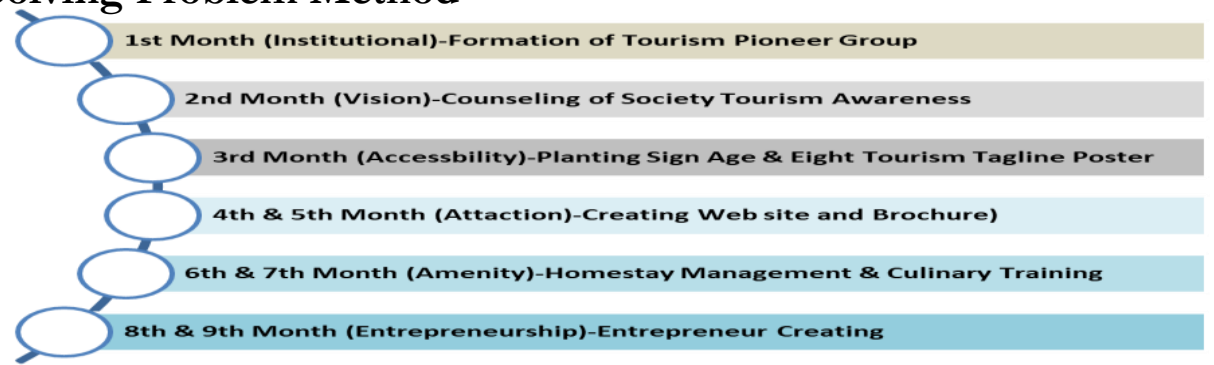

Figure 4. Solving Steps Chart Solving Problem Method

Tourism Research Journal, Volume 4 (2), 2020 
The Development of Thematic Tourist Village of Mulyaharja Bogor Based on Community Empowerment Approach

\section{Institutional Aspect}

Indeed, the problems that tourism pioneer group has not yet formed, it has already been formed in 2017, just need to continue with the program's optimization. It is more perceived by its members consisting of the adult farmers group and the women farmers group. Actually, there is an evaluation of the organizational structure, replacing administrators who are no longer actively involved with new ones who are more active.

\section{Vision Aspect}

Due to the problem for being inactively tourism pioneer group in the community, then by implementing counseling toward the enchantment of the group, village administrators, thematic tourist village managers, business actors, community leaders, members of women farmer groups and adult farmer groups and young people group, it is expected that the community will be more aware against eight of tourism tagline (Sapta Pesona). This is supported by the fact that the board sign of it has increasingly positive impacts.

\section{Accessibility Aspect}

Problems related to the absence of a signpost, then with the submission of 2 signages that have been planted at the T-junction BNR (Bogor Nirwana Residence) with Lemah Duhur Street and T-junction Lemah Duhur Street to the location. Hopefully, it will help the visitors who will travel to thematic tourist villages. The pointer board's quality supports this according to the standard, namely eye-catching, strong, easy to see and strategic places).

\section{Activity Aspect}

On the activity side, thematic tourist villages have reliable tourism products, namely Agro Edu Organic Tourism which consists of plowing rice fields using buffalo, seeding (spreading organic rice seeds directly in paddy fields), jurisdicting Legowo 2-1 by using caplakan tools, tandur (techniques for planting organic rice seeds), ngarambet (weeding, cleaning rice from weeds using lalandak), ngobaklauk (techniques for catching fish manually), harvesting to enjoy the results of plantations, fruits, vegetables.

This needs to be added again with other activities, which are looking at the gas processing system from livestock manure, processing compost, learning to manage waste with the $3 \mathrm{R}$ system (Reduce, Recycle, Reuse), learn about the new paradigm of handling household waste, learn how to process tempeh, learning catfish cultivation, learning pharmacies life, life stalls, live barns and live banks. The last is discussion, questions and answers, sharing about organic farming with agricultural extension officers as well as thematic tourist village managers and leaders of adult farmer groups. 
The Development of Thematic Tourist Village of Mulyaharja Bogor Based on Community Empowerment Approach

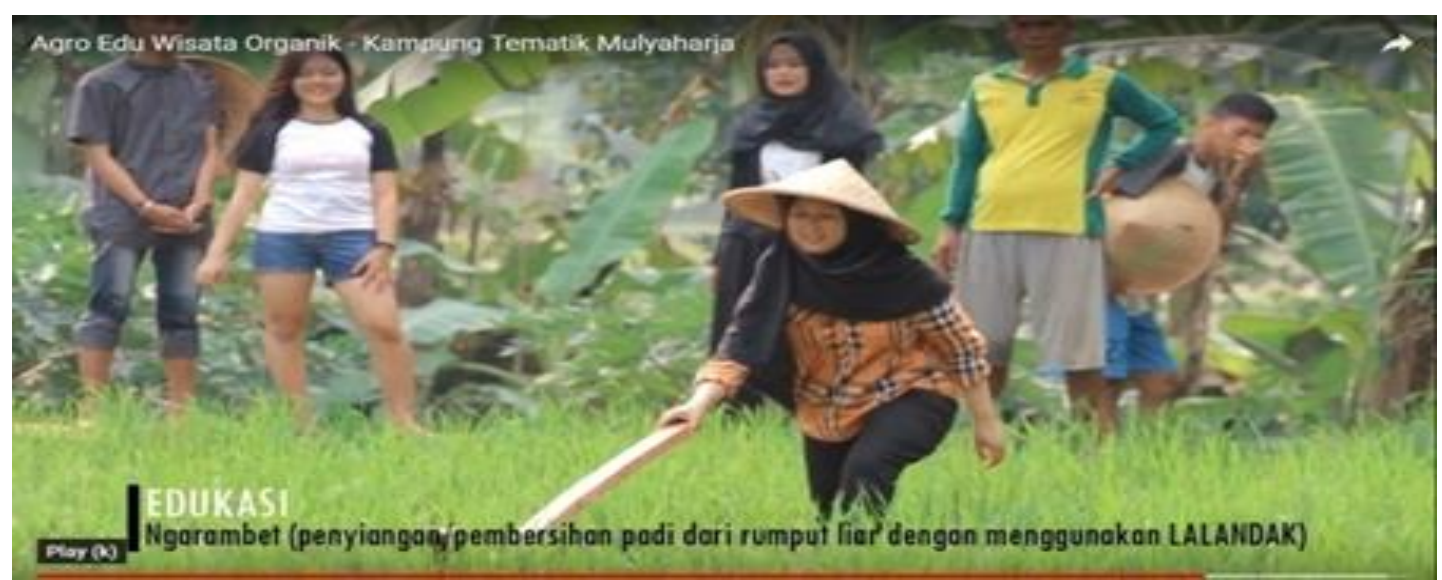

Figure 5. One of the attractions of Agro Edu Tourism is Organic Ngarambet Using Lalandak

Source:

(https:/ /www.youtube.com/watch?v $=$ w0UOR4ZwaT0\&feature=youtu.be, 2018)

The activities mentioned above need to be promoted through online media that visitors often access, namely youtube and the web site. The tour package already exists on YouTube, then what is needed is creating a website. In this case, the draft has been made, namely www.kampungtematikciharashas.com.

\section{Amenities Aspect}

In terms of amenities, the thematic village already has twenty homestays that are ready to be inhabited by visitors. This is already common when large groups of schools come. The problem is that there is no standardization in terms of its management. Therefore, by holding counseling on homestay management, sanitation hygiene and toilet care, it will improve its services.

On the other hand, there is an obstacle to the lack of souvenir products as a souvenir to identify the place's uniqueness. Therefore, by handling the training about processing rice bran into cookies and sweet potatoes to pizza, it will hopefully be an icon. This is because rice bran and sweet potato are very abundant in Mulyaharja, so it is used as a program to create culinary innovations made from local ingredients.

\section{Entrepreneurship Aspect}

Several businesses have been running, namely dodol, banana chips, pia blooms, tempeh as food home industry. Furthermore, sandal shoes home industry which is dropped to Tanah Abang big traditional market in Jakarta. It is an initial capital towards an independent community related to entrepreneurship. However, this needs innovation through product designing, packaging, pricing and marketing. With this training of entrepreneurship, it will encourage the

Tourism Research Journal, Volume 4 (2), 2020 
The Development of Thematic Tourist Village of Mulyaharja Bogor Based on Community Empowerment Approach

development of an entrepreneurial spirit towards communities, especially those based on agro-industry.

\section{Community Empowerment Model}

Refers to the results and discussion above, it can be designed the model of development of thematic tourist village with community empowerment approach as follows:

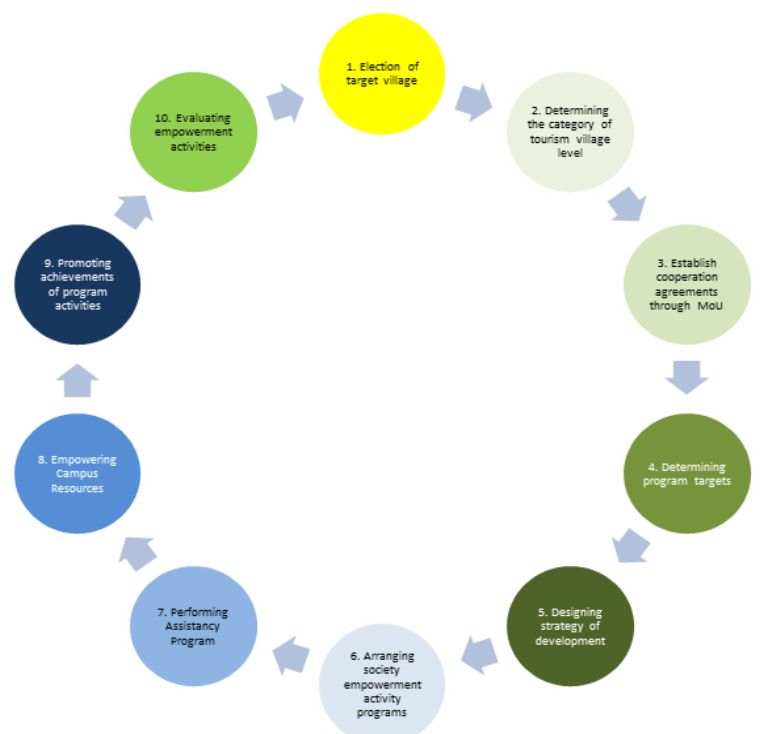

Figure 6. The Community Empowerment Model in the Tourism Village Based on University Assistance

Series of steps in Development of thematic tourist village based on community empowerment approach:

1. Electing of target village candidates.

Choose prospective foster villages in accordance with predetermined requirements, including high motivation from the head of village office or Lurah to become a fostered village, willing to do the cooperation as stated in the Memorandum of Understanding, the village has a unique tourism potential and can be developed. Then choose the village location which is not too far from the area of our campus because it will affect the implementation of mentoring activities in the future.

2. Determining the category of tourist village level.

Identifying the target villages to include them in the pioneering category of embryo tourist villages, developing tourist villages, or developed tourist villages.

3. Establishing partnership agreements through the Memorandum of Understanding.

Performing an MoU (Memorandum of Understanding) or cooperation agreement between the University and the Patronage Village to collaborate in

Tourism Research Journal, Volume 4 (2), 2020 
The Development of Thematic Tourist Village of Mulyaharja Bogor Based on Community Empowerment Approach

the field of village development into a tourist village. For a period of time, usually 1 year or 2 years, based on the needs.

4. Deciding program targets.

Listing what the program targets will be achieved so that the assistance program's implementation can be monitored at what percentage of outcomes have been achieved. How long the program will run, how many tourist attractions will be displayed, how much the price of tour packages will be sold, tour guides to be trained, how many homestays will be formed, how many souvenir sellers will be raised, how many visitors will be reached, web site design such as what will be made, how many sign ages, ten of tourism tag line boards, trash bins to be made, what culinary products and souvenirs will be used as icons. This is flexible, in accordance with the needs.

5. Designing strategy of development.

Identify strengths, weaknesses, opportunities and threats owned by the village, then a strategy is designed to develop the village towards a tourist village, this can be done through focus group discussion by inviting village officials, community leaders, young people, homemakers of economic actors. Seeing the potential is agricultural products, then stakeholders involved must aggressively carry out promotions, find out what tourists want, and encourage synergies between local governments and managers in their development programs (Yenny et al., 2015).

Observing the profile of visitors who are mostly students, a sustainable development for the future is education-based tourism. It needs to be studied in depth about what needs to be prepared to implement it (Maryetti et al., 2016).

6. Arranging community empowerment activity programs.

Check the institutional completeness of a tourist village, i.e. do you have a tourist village structure, a pokdarwis structure (tourism pioneer group), are programs running well, are people actively involved in tourism pioneer group, are there activities promoting the village tourism, whether there are visitors either individuals or agencies, how many activities have been carried out and how many visitors have come, whether they have a homestay, whether they have met the standard, whether they already have a tour package, what is the price of the package, how much income is derived from the impact of tourism, whether it already has promotional facilities such as web sites, vlogs, blogs or social media, banners, sign age, eight tourism tagline boards.

7. Performing the Assistancy Program.

a. Conduct counseling activities about tourism awareness, eight tourism tagline, tourist village, homestay.

Tourism Research Journal, Volume 4 (2), 2020 
The Development of Thematic Tourist Village of Mulyaharja Bogor Based on Community Empowerment Approach

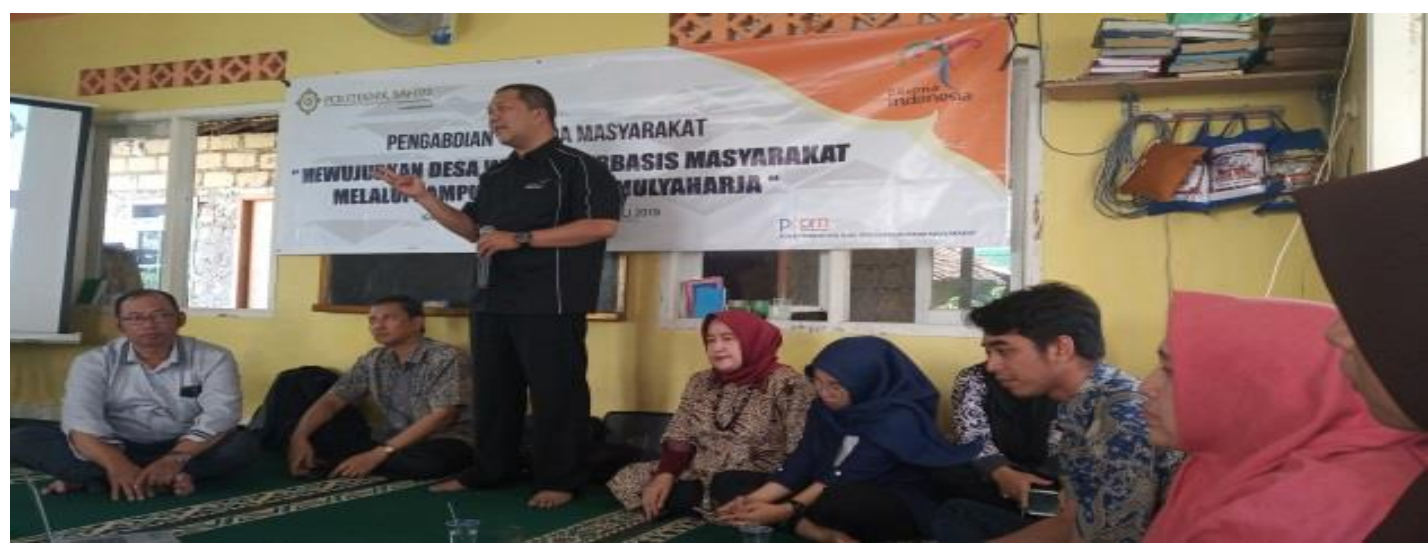

Figure 7. Counseling Tourism Awareness, Eight Tourism Tag Line, Tourism Village And Homestay

b. Counseling of entrepreneurship, marketing, sanitation hygiene, toilet care, housekeeping, food and beverage service or table manner, front office or reception, culinary processing made from local or culinary procedures, followed by training or direct practice.

c. Counceling about 4A (Accessibility, attraction, amenities, ancilliary).

1) Accessibility, how about road infrastructure, is it easily accessible from major roads or from the city center, is public transportation available, is the location easily accessible using the help of google maps, can the road to the location be covered by large buses, minibus vehicles or motorbike, is the road feasible and comfortable, is there a welcome gate, signage or signpost to the location.

2) Attraction, or tourist attractions, anything that can be used as a tourist attraction whether there is an element of something to do, something to buy, something to see, whether it has contained elements of cultural tourism, natural tourism or artificial tourism.

3) Amenities, or facilities, whether there is a decent homestay inhabited by visitors, whether it has been managed according to standards, whether there is a souvenir shop that sells souvenirs of the village treasury both culinary and art and craft, shops selling daily necessities.

4) Ancillary or institutional, is there a tour agency that liaises with tourists, is there a tour guide available, whether there are facilities for promotion of tourist destinations, ticket reservations.

d. Institutional formation.

Along with the implementation of the community empowerment program, conduct a study on the tourist village institutions, if not yet formed, establish the formation of the structure of the tourist village and tourism pioneer group following the issuance of a decree. Furthermore, creating a vision, mission and program of activities must be in accordance with local culture. If it has been formed, do a study on its

Tourism Research Journal, Volume 4 (2), 2020 
The Development of Thematic Tourist Village of Mulyaharja Bogor Based on Community Empowerment Approach

implementation, whether the tourist village or tourism pioneer group has been going well or passively. If it is passive, inventories any obstacles and make a SWOT analysis.

8. Directing college resources.

To strengthen the mentoring activities in the target villages, direct the campus resources to focus on it, such as student theses, tour guide courses, MICE lectures, entrepreneurship courses, lecturers' community service activities. Lead students to make tour packages, create vlogs, processing culinary made from local ingredients, design packaging, do digital marketing and stay overnight in homestays in the target villages.

9. Promoting achievements of program activities.

To enlarge the branding of our fostered village as a tourist village, then promote all forms of activities carried out during the mentoring program through various media, youtube, web sites, instagram, whatsapp, facebook, twitter and other social media, including print media such as newspapers, news on line, campus community service website and so on.

10. Evaluating of empowerment activities.

According to (Wibowo et al., 2015) stated that the factors that cause the failure of a community empowerment program in agro-tourism are decreased community participation, lack of coordination between sectors and not implementing community-based tourism. In the process of evaluating of empowerment, what we need to pay attention to are:

a. Trust.

Assest to the fostered village's trust towards us as an academician that has undertaken community empowerment programs. If it did well, then continued to strengthen and maintain the friendship, but if it has not been immediately addressed, pay attention to key figures (key people) while running the program (head of village office, youth leader, field instructor, chief of tourism pioneer group or others who can help).

b. Community involvement.

Observe on community involvement in empowerment activities that have been carried out, if there are obstacles then solve them by doing the focus group discussion to find out the obstacles faced and to determine the solution, because of it, opinions, input and criticism from the community can be explored.

c. Outcomes.

Make an assessment, what percentage of the target output has been achieved. Following the MoU period, what kind of programs that have been reached, if there were development inaction, then it needs prescribing corrective action.

d. Change the way of community thinking.

Due to a change in the community's way in terms of independence, it can be seen from tourism awareness, whether the public has begun to realize

Tourism Research Journal, Volume 4 (2), 2020 
The Development of Thematic Tourist Village of Mulyaharja Bogor Based on Community Empowerment Approach

tourism. Furthermore, from the implementation of the eigth tourism tag line, whether it has been implemented in everyday life. This can be seen from the cleanliness of the environment from waste. In addition is whether there have been emerging entrepreneurs/entrepreneurs or new entrepreneurs, if there are already how many and what business fields. More than that, changing people's perspective to shift from conventional farming methods to organic farming methods can be very valuable, but this is not our portion. It requires collaborative work of broader crossstakeholder, including the central, regional, local governments and all parties who play a role in it.

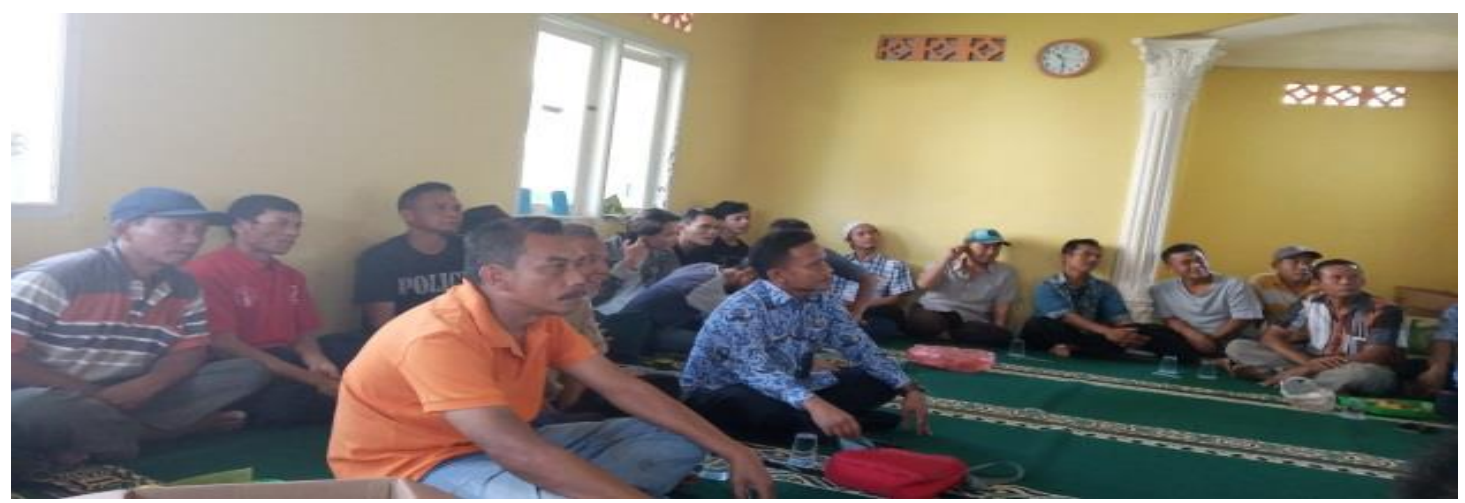

Figure 8. Society Involvement

11. Mapping stakeholder based on their engagements during implementation the program. Actually, various parties have interest toward this program. Every party has interest based on its role and status in system. Stakeholder mapping is a collaborative process of research, debate, and discussion that draws from multiple perspectives to determine a key list of stakeholders across the entire stakeholder spectrum. Mapping can be broken down into four phases:

a. Identifying (listing relevant groups, organizations, and people)

b. Analyzing (understanding stakeholder perspectives and interests)

c. Mapping (visualizing relationships to objectives and other stakeholders)

d. Prioritizing (ranking stakeholder relevance and identifying issues) (BSR, 2011).

In practice, there are governments, communities and academician who are directly involved during program implementation. The government is represented by the village office, the community is represented by adult farmer groups, youth groups and adult female farmer groups, while academician are the Sahid Polytechnic campus as the organizer of the activity program. Basically, all parties welcomed this activity positively, this can be seen from the simplicity of communication that was established among of us. Each party contributes according to their respective roles and portions. And the government and community also look professional and friendly. The head of the village, in this

Tourism Research Journal, Volume 4 (2), 2020 
The Development of Thematic Tourist Village of Mulyaharja Bogor Based on Community Empowerment Approach

case, is Bapak Sofyan Makmur, who is the highest decision maker so that he is able to coordinate the social institutions under him, including the youth organizations and particular community organizations. This is supported by $\mathrm{Pa}$ Gandhi as the village secretary, a new person but very energetic in collaborating with us, a low profile and friendly figure as a community servant in the village. Next, head of the youth organization, Bang Oji, is a contact person who roles as the communication link among us.

Meanwhile, Mas Imam and Bapak Oneng were key speakers who had a better understanding of organic agriculture. As we know, Mas Imam was a field agricultural extension agent (Penyuluh Pertanian Lapangan). he is a firm figure and is very experienced in the field of agricultural management. His explanation regarding organic farming is very easy to accept and understand by all groups. While $\mathrm{Pa}$ Aneng was an organic farmer and leader of Lemah Duhur adult farmer group. He is honest and very simple but a hard worker as a farmer and leader. Last but not least, the key figure is Bang Oji as the head of the youth organization, because the speed of information delivered by academician depends on the response he gives. The problem is when there are many activities in the village office that involve him, the response is fast as usual, but for execution will take longer. The key points that we must aware in building partnerships among stakeholders are time management, communication skills, mutual respect, and commitment in maintaining relationships considering the busyness and spare time between us.

\section{E. Conclusion}

This study's first objective has been met by framing a simple problemsolving step method in Figure 3 which was carried out for eight months consisting of institutional, vision, accessibility, attractions, amenities, and entrepreneurship aspect. This method is not an effective remedy to solve the problems in Mulyaharja with its complexity but is quite effective in minimizing the obstacles faced. The creation of a community empowerment-based thematic village development model has answered the second research objective. A series of steps totaling eleven stages is one unity that is related to one another and is continuous. Therefore it has the shape of a circle which is expected to continue rotating in the aim of its evaluating. This model is incomplete as long as it has not been successfully applied in other areas. However, at least, it can provide a fairly regular and gradual picture that can be used as a guide in the development of a village, even not only for tourist villages but also for villages that want to develop based on its local resources.

During the program, a perceived impression was very pleasant in collaboration with village people, most of whom were innocent, friendly and what they were, but they had an extraordinary work spirit and abundant of potentials that needed to be explored and directed to become very precious resources that beneficial toward village progress. The program's success really

Tourism Research Journal, Volume 4 (2), 2020 
The Development of Thematic Tourist Village of Mulyaharja Bogor Based on Community Empowerment Approach

relies on $3 \mathrm{C}$, i.e. our concern, commitment, and communication style of academicians as the program organizer.

Future research is recommended to apply these methods and models in other villages that definitely have different potential and stakeholder characteristics. Doubtless, it will generate significant new findings in community empowerment studies for thematic tourist village development.

\section{REFERENCES}

Arikunto, S. (1998). Prosedur Penelitian (Suata Pendekatan Penelitian Praktek). Jakarta: PT Rineka Cipta.

Bachri, B. S. (2010). Mayakinkan Validitas Data Melalui Triangulasi Pada Penelitian Kualitatif. Jurnal Teknologi Pendidikan, 46-62.

BSR. (2011, November). Retrieved from http://gsvc.org/wpcontent/uploads/2016/10/Stakeholders-Identification-and-Mapping.pdf

Gurindawangsa, S. A., Topowijono., \& Supriyono. (2017). Analisis Strategi Pengembangan Produk Agrowisata (Studi Pada Desa Wisata Gubugklakah Kec. Poncokusuma Kab. Malang Jawa Timur). Jurnal Administrasi Bisnis (JAB), 141-150.

Hadiwijoyo, S. S. (2012). Perencanaan Pariwisata Berbasis Perdesaan (Sebuah Pendekatan Konsep). Yogyakarta: Graha Ilmu.

Hendryantoro, A. (2014). Pemberdayaan Masyarakat Melalui Pengembangan Desa Wisata dan Implikasinya Terhadap Ketahanan Sosial Budaya. Jurnal Ketahanan Nasional, 49-57.

https: / / www.youtube.com/watch? $v=$ w0UOR4ZwaT0 E.feature=youtu.be.

September). Retrieved from https://www.youtube.com/watch? $\mathrm{v}=$ w0UOR4ZwaT0\&feature $=$ youtu.be

Kemendagri. (2019, May). www.prodeskel.binapemdes.kemendagri.go.id. Retrieved from www.prodeskel.binapemdes.kemendagri.go.id:https:www.prodeskel.binapemdes.keman dagri.go.id

Kementerian Pariwisata. (2019). Program Pendampingan Desa Wisata. Jakarta: Tim Master Trainer Kementerian Pariwisata.

Maryetti, Sulistyadi, Y., Damanik, D., Nurhidayati, H., \& Wibowo, F. S. (2016). Pengembangan Berkelanjutan Kampung Budaya Setu Babakan sebagai Daya Tarik Wisata. Jurnal Destinasi Kepariwisataan Indonesia, 27-44.

Mayrowani, H. (2012). Perkembangan Pertanian Organik Indonesia. Forum Penelitian Agro Ekonomi, 91-108.

Moleong, L. J. (2008). Metodologi Penelitian Kualitatif. Bandung: PT Remaja Rosdakarya.

Politeknik Sahid. (2019, Juni). https://www.youtube.com/watch?v=PY1ph7d-YiO. Retrieved from https://www.youtube.com/watch?v=PY1ph7d-Yi0

Tourism Research Journal, Volume 4 (2), 2020 
The Development of Thematic Tourist Village of Mulyaharja Bogor Based on Community Empowerment Approach

Politeknik Sahid. (2019, Juni). wmw.kampungtematikciharashas.com. Retrieved from www.kampungtematikciharashas.com

republika.co.id. (2018, April 11). Belajar Pertanian Organik Melalui Kampung Agro Eduwisata. Jakarta, DKI Jakarta, Indonesia: Republika.co.id.

Simanungkalit, V. B., Sari, A. D., Teguh, F., Ristanto, H., Permanasari, I. K., Simbodo, L., \& Vitriani, D. (2012). Buku Panduan Pengembangan Desa Wisata Hijau. Jakarta: Kementerian Koperasi dan UKM Republik Indonesia.

Sugiyono. (1997). Metode Penelitian Bisnis. Jakarta: PT Gramedia Pustaka.

Susanto, S. (1999). Manajemen Perguruan Tinggi berwawasan entrepeneur tinjauan filsafati, konsep, strategi dan kebijakan implementasi. Yogyakarta: Universitas Gadjah Mada.

Tamara, A. P., \& Rahdriawan, M. (2016). Kajian Pelaksanaan Konsep Kampung Tematik di Kampung Hidroponik Kel. Tanjung Mas Kota Semarang. Jurnal Wilayah dan Lingkungan, 141-150.

Wahyuni, D. (2018). Strategi Pemberdayaan Masyarakat Dalam Pengembangan Desa Wisata Nglangeran, Kabupaten Gunung Kidul. Aspirasi: Jurnal Masalah-Masalah Sosial, 83-100.

Wardhani, A. A. (2016). Peran Pokdarwis Dalam Pengembangan Desa Wisata Dewi Sri. Artikel Ilmiah Program Studi Destinasi Pariwisata, Fakultas Teknologi Informasi Universitas Kristen Satya Wacana Salatiga, Jawa Tengah, Indonesia.

Wibowo, F. S., \& Damanik, D. (2019). Innovation and Marketing for Culinary of Local Based Food Product in Iwul Village Bogor. The 5th International Conferences on Cultural Studies, pp. 296-305, Denpasar: Udayana University.

Wibowo, F. S., Harapan, A. D., Damanik, D., \& Nurhidayati, H. (2015). Pemberdayaan Masyarakat dalam Agrowisata Belimbing Dewa di Kelurahan Pasir Putih Depok Jawa Barat. Tourism Scientific Journal, 61-84.

Yenny, M., Wibowo, F. S., Eddyson, J. M., Yanuarita, T., \& Augusrini, N. (2015). Kajian Pengembangan Agrowisata di Kawasan Puncak Cianjur Jawa Barat. Jurnal Destinasi Pariwisata, 37-61. 